\title{
Plant Biomass and Soil Nutrients Mainly Explain the Variation of Soil Microbial Communities during Secondary Succession on the Loess Plateau
}

\section{Miao-Ping $\mathrm{Xu}$}

College of Agronomy

Jia-Yi Wang

College of Agronomy

Xin-Hui Han ( $\square$ hanxinhui@nwsuaf.edu.cn )

College of Agronomy

Cheng-Jie Ren

College of Agronomy

Gai-He Yang

College of Agronomy

\section{Research Article}

Keywords: Vegetation restoration patterns, Soil bacteria and fungi, Plant characteristics, Soil properties

Posted Date: February 10th, 2021

DOl: https://doi.org/10.21203/rs.3.rs-160925/v1

License: (c) (i) This work is licensed under a Creative Commons Attribution 4.0 International License. Read Full License

Version of Record: A version of this preprint was published at Microbial Ecology on March 20th, 2021.

See the published version at https://doi.org/10.1007/s00248-021-01740-9. 


\section{Abstract}

Soil microorganisms play an important role in the circulation of materials and nutrients between plants and soil ecosystems, but the drivers of microbial community composition and diversity remain uncertain in different vegetation restoration patterns. We studied soil physicochemical properties (i.e., soil moisture, bulk density, pH, soil nutrients, available nutrients), plant characteristics (i.e., Shannon index $\left[H_{P l a n t}\right]$ and Richness index [ $\left.S_{\text {Plant }}\right]$, litter biomass [LB], and fine root biomass [FRB]), and microbial variables (biomass, enzyme activity, diversity and composition of bacterial and fungal communities) in different plant succession patterns (Robinia pseudoacacia [MF], Caragana korshinskii [SF] and grassland [GL]) on the Loess Plateau. The herb communities, soil microbial biomass and enzyme activities were strongly affected by vegetation restoration. And soil bacterial and fungal communities were significantly different from each other at the sites. Furthermore, LB and FRB were significantly positively correlated with $S_{\text {Bacteria }}$, soil microbial biomass, enzyme activities, Proteobacteria, Zygomycota and Cercozoa, while negatively correlated with Actinobacteria and Basidiomycota. In addition, soil water content (SW), $\mathrm{pH}$ and nutrients have important effects on the bacterial and fungal diversities, Acidobacteria, Proteobacteria, Nitrospirae, Zygomycota and microbial biomass. Furthermore, plant characteristics and soil properties modulated the composition and diversity of soil microorganisms, respectively. Overall, the relative contribution of vegetation and soil to the diversity and composition of soil bacterial and fungal communities illustrated that plant characteristics and soil properties may synergistically modulate soil microbial communities. And soil bacterial and fungal communities mainly depend on plant biomass and soil nutrients.

\section{Introduction}

Plant secondary succession is an effective way to improve soil conditions and promote ecosystem restoration $[1,2]$. Changes in plant community characteristics and soil physicochemical properties may drive changes in microbial communities among different succession styles [3]. On the one hand, the succession of undergrowth vegetation, the decomposition of litter, and changes of rhizosphere carbon inputs drive growth and activity of soil microbes [4]. On the other hand, changes in soil properties such as $\mathrm{pH}$, moisture, clay content, $\mathrm{C}, \mathrm{N}$, and phosphorus availability have significant effects on soil microbial communities under different land types $[5,6]$. Conversely, as the main driving force of ecosystem processes, soil microorganisms complete the decomposition of soil organic matter and plant litter, and mediate the nutrient cycle of plant-soil ecosystems [7]. Therefore, understanding the coupling relationships among plant characteristics, soil properties, and microbial communities among different succession styles provides insight into the adaptation and response mechanisms of soil microorganisms in plant and soil ecosystems.

The change of soil microbial community caused by plant succession is a complex process, which is regulated by many biotic and abiotic factors $[1,8]$. Recent research has explored how environmental changes (such as plant diversity, underground vegetation characteristics, $\mathrm{pH}$, soil nutrients, and soil moisture) affect soil microbial communities on a local scale, however the results are equivocal $[9,10]$. 
Some studies indicated that plant diversity was predicted to promote the diversity of soil microorganisms by increasing the diversity of available nutrient pools and physical microhabitats, and by providing diverse plant hosts for symbiotic and pathogenic microorganisms [11]. And increased in vegetation coverage changed soil moisture and solar radiation, which in turn drives the diversity of soil microbial communities [1, 12]. Furthermore, abiotic factors such as soil nutrients and humidity have also proven to be key factors in building microbial communities [13]. Some studies indicated that lower soil nutrient availability may promote fungal growth in soil, as fungi have a competitive advantage related to nitrogen and phosphorus absorption [14, 15], while other studies indicated that bacteria can adjust their lifestyle ( $r-$ or k-strategists) to change community composition to adapt to nutritional levels $[1,16]$. In addition, the shifts in the diversity and composition of soil microorganisms drive variables in microbial biomass and extracellular enzyme synthesis, which affect soil mineralization and nutrient availability $[17,18]$. Among

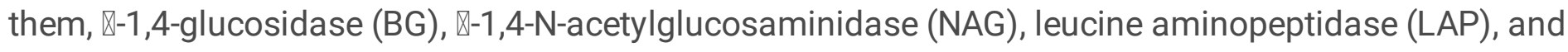
acid or alkaline phosphatase (ALP) have been increasingly used to indicate nutrient deficiency and microbial nutrient demand [19]. Therefore, the relative contribution of vegetation factors and soil properties in determining microbial communities remain unclear, especially under distinct vegetation succession patterns.

The Loess Hilly Region of China is severely affected by soil erosion and desertification, which has accelerated the fragmentation and degradation of the ecosystem [20,21]. To change these conditions, the Chinese government has taken various measures to repair the ecosystem and counteract soil erosion since 1950s [22]. These measures include the Grain to Green Project, which have increased vegetation coverage and improved soil erosion on the Loess Plateau [22,23]. Notably, most of the farmland and pastures were afforested or abandoned [19]. The effects of different vegetation restoration styles on soil physical and chemical properties, microbial dynamics, and plant characteristics have been concerned [24, 25]. However, information on the links between them is still scarce, especially among different plant succession patterns. This information is critical to understanding the driving mechanisms of soil microbial communities and the proper management and protection of fragile ecosystems.

To illustrate the changes in the dominant factors affecting soil microbial communities in the hilly and gully regions of Loess Plateau, we studied soil physicochemical properties, plant characteristics, and microbial variables (biomass, enzyme activity, diversity and composition of bacterial and fungal communities) in different plant succession patterns. We hypothesized that the diversity and composition of soil bacterial and fungal communities responded differently to drivers, which is attributed to survival strategies of bacterial and fungal communities. We also hypothesized that there is a inseparable correlation between vegetation characteristics and soil microbial diversities, as increased in litter production, soil nutrient input and microbial biomass after afforestation. Therefore, the objectives of the study were to (i) describe the differences in soil properties, vegetation communities, and microbial characteristics under different plant succession patterns; (ii) explore whether soil properties and vegetation characteristics have different effects on fungal and bacterial diversity; (iii) determine the main driving factors for the composition and diversity of soil microbial communities under different succession patterns. 


\section{Materials And Methods}

\section{Study Area and Experimental Design}

The study was carried out in Wuliwan watershed, located in the Loess Plateau region of Shaanxi Province $\left(36^{\circ} 51^{\prime} 13.42^{\prime \prime}-36^{\circ} 52^{\prime} 17.36^{\prime \prime} \mathrm{N}, 109^{\circ} 20^{\prime} 53.44^{\prime \prime}-109^{\circ} 21^{\prime} 26.64 " \mathrm{E}\right.$; Fig. S1). The region is characterized by annual average precipitation of $510 \mathrm{~mm}$, rainfall mainly occurring from July to September, the annual average temperature of $8.8^{\circ} \mathrm{C}, 2415 \mathrm{~h}$ of sunshine, and 157 days of frost-free period each year. The soil is mainly of typical loess texture and overall looseness (judged by the Food and Agriculture Organization of the United Nations). Beginning in the late 1989s, most of farmland was replanted with forest. Robinia pseudoacacia and Caragana korshinskii are the main tree species in the artificial planting area, used because of their drought tolerance and water conservation. Some abandoned farmlands have gradually replaced natural grasslands.

The experiment was conducted in July 2018, which coincided with the growing season in the forest area. Three types of land use were selected, namely Robinia pseudoacacia (macrophanerophytes forest, MF), Caragana korshinskii (shrub forest, SF) and grassland (GL) with similar geographical features and soil types. Each type of land use was represented by three independent replicate sites. All selected sites were located at similar gradients, slope aspects, elevations, and the main crops of maize were alternately planted at these sites before afforestation (Table 1). Three $20 \mathrm{~m} \times 20 \mathrm{~m}$ plots were established in each site. The typical distance between different stand age classes was more than $2 \mathrm{~km}$ apart, and the replications of the same stand age class exceeded $1 \mathrm{~km}$.

Table 1

The geographical information of the three land types.

\begin{tabular}{|c|c|c|c|c|}
\hline Sites & $\begin{array}{l}\text { Gradient } \\
\left(^{\circ}\right)\end{array}$ & $\begin{array}{l}\text { Slope } \\
\text { aspect }\left({ }^{\circ}\right)\end{array}$ & $\begin{array}{l}\text { Altitude } \\
\text { (m) }\end{array}$ & Understory vegetation \\
\hline GL & 30 & 103 & $\begin{array}{l}1250- \\
1260\end{array}$ & L. floribunda B. T. vulgare N. \\
\hline SF & 20 & 317 & $\begin{array}{l}1250- \\
1260\end{array}$ & $\begin{array}{l}\text { P. heterophylla B. } \\
\text { D. indicum (L.) D. M. }\end{array}$ \\
\hline MF & 40 & 303 & $\begin{array}{l}1270- \\
1280\end{array}$ & $\begin{array}{l}\text { Dendranthema indicum (L.) Des Moul. P. sphondylodes } \\
\text { T. P. heterophylla B. }\end{array}$ \\
\hline
\end{tabular}

\section{Sampling And Vegetation Investigation}

After removing the litter layer and other debris, soil samples of the $0-10 \mathrm{~cm}$ profile were collected from 10 points arranged in the $S$ shape using a soil auger $(5 \mathrm{~cm}$ in diameter). The soil samples were homogenized to create the final soil samples, which were then sieved through a $2 \mathrm{~mm}$ mesh to remove roots and other 
debris. A portion of each soil sample was immediately shipped to the lab to determine soil water content. A set of subsamples were stored at $-80^{\circ} \mathrm{C}$ for DNA extraction, and the remaining soil subsamples were air dried and stored at room temperature to assess soil chemistry and $\mathrm{pH}$.

Plant characteristics were measured in six $1 \times 1 \mathrm{~m}$ quadrats were randomly arranged in each plot. Six $1 \mathrm{~m}$ $\times 1 \mathrm{~m}$ sample quadrats were created in each plot to assess plant diversity, biomass and coverage of the herb layer as well as biomass of the litter layer. In each quadrat, the name and number of the undergrowth plant species were recorded, and the coverage of that was measured. Plant coverage (HC) was calculated as the average percentage of ground surface covered by the shadow of the foliage in each quadrat. Above-ground parts of all plants in each quadrat were collected by shearing, dried to constant weight at $75^{\circ} \mathrm{C}$, and above-ground biomass (HB) was calculated. The calculation formulas of Shannon-Wiener diversity index $\left(H_{\text {Plant }}\right)$ and Margalef richness index $\left(S_{\text {Plant }}\right)$ for each sample are as follows [26]:

$$
H_{\text {Plant }}=-\sum_{j=1}^{s}\left(p_{i} \ln p_{i}\right)
$$

1

$$
S_{\text {Plant }}=\frac{S-1}{\operatorname{Ln}(N)}
$$

where $\mathrm{S}$ is the species number in a plot; $\mathrm{N}$ is the sum of all species in a plot; $\mathrm{Ni}$ is the number of the species " $\mathrm{i}$ " in a plot; $\mathrm{Pi}$ is the density proportion of species " $\mathrm{i}$ " in a plot $(\mathrm{Pi}=\mathrm{Ni} / \mathrm{N})$; $\mathrm{Ln}=$ natural $\log$.

The litter layer samples were collected from each study site using nine spatially independent subsamples from litter traps without understory vegetation. The litter was dried to constant weight at $75^{\circ} \mathrm{C}$ to obtain litter biomass (LB). While other measurement methods were performed, fine-root ( $<2 \mathrm{~mm}$ diameter) samples were collected at the $0-10 \mathrm{~cm}$ depth with a $9-\mathrm{cm}$ diameter stainless steel drill in each plot, and these samples also matched the plant quadrats. The roots were separated from the soil, washed repeatedly with water, then dried in an oven at $60^{\circ} \mathrm{C}$ for 48 hours and the fine root biomass (FRB) was weighed.

\section{Analysis Of Soil Properties}

Soil $\mathrm{pH}$ was measured with a $\mathrm{pH}$ meter after shaking the soil-water $(1: 5 \mathrm{w} / \mathrm{v})$ suspension for $30 \mathrm{~min}$. Soil bulk density (SBD) was obtained by calculating the ratio of soil mass to total volume of the core $\left(\mathrm{g}^{\cdot \mathrm{cm}^{-3}}\right)$ after oven-drying to a constant weight at $105^{\circ} \mathrm{C}$. Soil water content (SWC) was determined by oven drying the secondary samples to constant mass at $105^{\circ} \mathrm{C}$. The content of soil clay (Clay) was determined by a laser particle-size analyzer (Mastersizer, UK). Soil organic carbon (SOC) was determined by the 
$\mathrm{K}_{2} \mathrm{Cr}_{2} \mathrm{O}_{7}$ oxidation method, and the soil $\mathrm{N}$ and $\mathrm{P}$ contents were determined by the Kjeldahl and colorimetric method, respectively. Soil dissolved organic carbon (DOC) was analyzed using the TOC analyzer (TOC-L CPH, Shimadzu, Japan). Ammonia nitrogen $\left(\mathrm{NH}_{4}{ }^{+}-\mathrm{N}, \mathrm{SAN}\right)$ and nitrate nitrogen $\left(\mathrm{NO}_{3}{ }^{-}{ }^{-} \mathrm{N}\right.$, SNN) of soil were measured using an AA3 continuous flow analysis system (AA3, Germany) and $1 \mathrm{~mol} \mathrm{~L}^{-}$ ${ }^{1} \mathrm{KCl}$ extraction. Soil available phosphorus (SAP) was measured using the spectrophotometer (Mapada corporation, China) with a $0.5 \mathrm{~mol} \mathrm{~L}^{-1} \mathrm{NaHCO}_{3}$ extraction. Soil microbial biomass carbon (MBC), nitrogen (MBN), and phosphorus (MBP) were determined using the chloroform fumigation-extraction method.

The activities of carbon-acquiring enzymes (BG), nitrogen-acquiring enzymes (LAP and NAG), and phosphorus-acquiring enzymes (ALP) was determine using the modified standard fluorometric techniques $[27,28]$. The four types of soil enzyme activity were measured using a 96-well plate with three replicate wells for each sample per assay. The analysis included 3 replicate wells for each blank, negative control, and quenched standard [19]. One gram of fresh soil was homogenized in $125 \mathrm{ml}$ of sodium acetate buffer $(\mathrm{pH}=8.5)$ to extract ecological enzymes. Then, the $200 \mu \mathrm{l}$ soil suspension and $50 \mu \mathrm{l}$ of $200 \mu \mathrm{mol} \mathrm{L}{ }^{-1}$ fluorometric substrate were added to the microplate. The fluorometric substrates of BG, LAP, NAG and AP were 4-MUB- $\beta$-D-glucoside, 4-MUB-N-acetyl- $\beta$-D-glucosaminide, L-leucine-7-amido-4methylcoumarin and 4-MUB-phosphate, respectively. In addition, 4-methylumbelliferone (MUB) or 7amino-4-methylcoumarin (AMC) was used as the standard substance. After the microplate was incubated for 4 hours at $25^{\circ} \mathrm{C}$ in the dark, $10 \mu \mathrm{L}$ of $0.5 \mathrm{~mol} \mathrm{~L}^{-1} \mathrm{NaOH}$ was added to each well to stop the reaction. Finally, the fluorometric values were measured using the microplate reader (Tecan Infinite M200 Pro Plex, Austria).

\section{Soil DNA Extraction and PCR Amplification}

Soil DNA was extracted with an E.Z.N.A soil DNA kit (Omega Bio-tek, Inc., Norcross, GA, USA) and electrophoresed on $1.0 \%$ agarose to check the quality and size of DNA. The extracted soil DNA was stored at $-80{ }^{\circ} \mathrm{C}$ until PCR amplification and analysis. The $16 \mathrm{~S}$ V3V4 (target fragment length $480 \mathrm{bp}$ ) and ITS1 (target fragment length $250 \mathrm{bp}$ ) regions in soil bacteria and fungi were amplified by PCR and sequenced. Soil bacterial $16 \mathrm{~S}$ rRNA targeting the V4 region by using primers 338F (5'- ACTCCTACGGGAGGCAGCA-3') and 806R (5'- GGACTACHVGGGTWTCTAAT - 3') [29]. The fungal ITS-1 region was amplified by using primers ITS5F (5'- GGAAGTAAAAGTCGTAACAAGG - 3') and ITS1R (5'- GCTGCGTTCTTCATCGATGC - 3') [30]. Soil bacterial $16 \mathrm{~S}$ rRNA amplification samples were denatured at $95^{\circ} \mathrm{C}$ for $3 \mathrm{~min}$, and then amplified by 27 cycles of $95^{\circ} \mathrm{C}$ for $30 \mathrm{~s}, 55^{\circ} \mathrm{C}$ for $30 \mathrm{~s}$, and $72{ }^{\circ} \mathrm{C}$ for $45 \mathrm{~s}$, which was followed by extension at $72{ }^{\circ} \mathrm{C}$ for $10 \mathrm{~min}$. PCR of the rRNA subunit was conducted in $25 \mu \mathrm{L}$ reaction mixtures containing $0.5 \mu \mathrm{L}$ of $30 \mu$ of each of 1-1 primers. The fungal ITS- 1 amplification samples were denatured at $95^{\circ} \mathrm{C}$ for $2 \mathrm{~min}$ and then amplified by 30 cycles of $95^{\circ} \mathrm{C}$ for $30 \mathrm{~s}, 55^{\circ} \mathrm{C}$ for $30 \mathrm{~s}$, and $72^{\circ} \mathrm{C}$ for $30 \mathrm{~s}$, which was then followed by a final extension at $72{ }^{\circ} \mathrm{C}$ for $5 \mathrm{~min}$. Three independent PCR assays were performed for each DNA sample to obtain replicates. Gene copy number was calculated by the standard curve method. The standard curve was generated by using 10 -fold-diluted series of plasmids containing each target gene. Finally, a total of the PCR products was achieved and an equal amount of PCR product from each sample 
was then transferred into the clean tubes and sequenced using Illumina's MiSeq platform at the Major Biological Institute, Shanghai, China.

\section{Sequence Data Processing}

Quality filtering of decomposed data. Sequence analysis was performed using USEARCH v5.2.32 after QIIME standard processing [29]. Similar sequences with less than $3 \%$ dissimilarity were clustered to to eliminate data noise. Combining clustering molecules with 97\% similarity, 16S rRNA and ITS rRNA operational taxa were selected for classification. Finally, the complete data were stored in the National Biotechnology Information Center (NCBI) Sequence Read Archive (SRA) database under the accession numbers of SRP243825 and SRP243837.

\section{Statistical Analyses}

Taxonomic alpha diversity was based on the diversity of soil microbial communities in individual samples, using the Chao index $\left(S_{\text {Bacteria }}\right.$ and $\left.S_{\text {Fungi }}\right)$ that reflected the richness of the community and the

Shannon index $\left(H_{\text {Bacteria }}\right.$ and $\left.H_{\text {Fungi }}\right)$ that took the uniformity of the community into account, was determined using Mothur software (version v.1.30.1). These indicators can accurately reflect the richness and uniformity of bacterial and fungi communities. A one-way analysis of variance (ANOVA) and multiple significant differences $(p<0.05)$ were used to assess the changes in soil properties $(S W, C l a y, S B D, p H$, SOC, DOC, STN, SAN, SNN, STP and SAP), plant characteristics (HC, HB, LB, FRB, $H_{\text {Plant }}$ and $\left.S_{\text {Plant }}\right)$ and soil microbial community diversity and composition. The data for this analysis were normalized via logtransformation. Principal component analysis (PCA) methods were used to assess soil microbial clusters across different land uses. Pearson correlation analysis were used to assess the relationships between dominant microflora and microbial community diversity and environmental variables (plant characteristics and soil properties). Redundancy analysis was used to identify the contributions of plant characteristics and soil properties on soil bacteria and fungi. Partial Least Squares Path (PLS-SM) analysis was used to evaluate the direct and indirect effects of plant characteristics and soil properties on soil microbial communities.

\section{Results}

\section{Variation in Vegetation Characteristics}

The composition, diversity, coverage and biomass of herb communities were strongly affected by land use from abandoned farmland (Tables 1 and 2). The significant increase in canopy closure from grassland (GL) to macrophanerophyte forest (MF) resulted in population classification changed from shady plants to light plants. The light plants such as Lespedeza floribunda B. and Tripolium vulgare $N$. were the dominant species in GL. The Dendranthema indicum and Patrinia heterophylla $B$. were gradually becoming the dominant species to replace the xerophytic species in SF. The shady plants such as Poa sphondylodes $T$. increased significantly in MF. The LB, FRB, and $H_{\text {Plant }}$ of undergrowth plant community increased significantly from GL to MF. The herb coverage (HC) of shrub forest (SF) was $51.75 \%$ and 
97.72\% higher than that of GL and MF, respectively. In addition, the HB and $S_{\text {Plant }}$ of SF were the largest compared to the other two land uses.

Table 2

The vegetation characteristics in the three land types.

\begin{tabular}{|c|c|c|c|c|c|c|}
\hline $\begin{array}{l}\text { Land } \\
\text { types }\end{array}$ & $\mathrm{HC}(\%)$ & $\begin{array}{l}\mathrm{HB}\left(\mathrm{kg} \cdot \mathrm{m}^{-}\right. \\
\left.{ }^{2}\right)\end{array}$ & $\begin{array}{l}\mathrm{LB}\left(\mathrm{kg} \cdot \mathrm{m}^{-}\right. \\
\text {2) }\end{array}$ & $\begin{array}{l}\mathrm{FRB}\left(\mathrm{kg} \cdot \mathrm{m}^{-}\right. \\
\left.{ }^{2}\right)\end{array}$ & $H_{\text {Plant }}$ & $S_{\text {Plant }}$ \\
\hline GL & $\begin{array}{l}53.33 \pm \\
5.88 \mathrm{~b}\end{array}$ & $\begin{array}{l}0.29 \pm \\
0.04 a b\end{array}$ & $\begin{array}{l}0.12 \pm \\
0.01 \mathrm{c}\end{array}$ & $0.13 \pm 0.01 c$ & $\begin{array}{l}2.54 \pm \\
0.13 \mathrm{~b}\end{array}$ & $4.51 \pm 0.10 b$ \\
\hline SF & $\begin{array}{l}80.93 \pm \\
4.30 \mathrm{a}\end{array}$ & $0.40 \pm 0.06 a$ & $\begin{array}{l}0.31 \pm \\
0.01 \mathrm{~b}\end{array}$ & $0.16 \pm 0.01 b$ & $\begin{array}{l}2.50 \pm \\
0.04 b\end{array}$ & $4.78 \pm 0.06 a$ \\
\hline MF & $\begin{array}{l}40.93 \pm \\
4.04 \mathrm{~b}\end{array}$ & $0.22 \pm 0.01 b$ & $\begin{array}{l}0.51 \pm \\
0.01 \mathrm{a}\end{array}$ & $0.18 \pm 0.01 a$ & $\begin{array}{l}2.68 \pm \\
0.11 \mathrm{a}\end{array}$ & $\begin{array}{l}4.67 \pm \\
0.33 a b\end{array}$ \\
\hline \multicolumn{7}{|c|}{$\begin{array}{l}\text { The values are mean } \pm \text { standard error. Different letters indicate significant differences }(p<0.05) \\
\text { among different land use types based on a one-way ANOVA followed by an LSD test. HC: herb } \\
\text { coverage; HB: herb biomass; LB: litter biomass; FRB: fine root biomass; } H_{\text {Plant }} \text { Shannon-Wiener } \\
\text { diversity index; } S_{\text {Plant }} \text { Margalef richness index; GL: grassland; SF: Caragana korshinskir; MF: Robinia } \\
\text { pseudoacacia. }\end{array}$} \\
\hline
\end{tabular}

\section{Variation In Soil Properties}

The SOC, STN, DOC, SNN, SW, and Clay were significantly different among different secondary succession patterns (Table 3). The contents of SW and SAN were greater in MF sites, relative to GL and SF sites. Compared with GL sites, Clay, STN and SNN contents were higher in SF and MF sites, while SBD was inverted. Furthermore, compared with the GL sites, the SOC contents increased by $14.89 \%$ and $17.80 \%$ in the SF and MF sites, respectively; the DOC contents increased by $75.42 \%$ and $102.76 \%$ in the SF and MF sites, respectively. In addition, STP, SAP, and pH did not differ significantly among different land use patterns. 
Table 3

The soil physicochemical properties in the three land types.

\begin{tabular}{|c|c|c|c|}
\hline Land types & GL & SF & MF \\
\hline SW (\%) & $8.32 \pm 0.46 b$ & $8.81 \pm 0.36 b$ & $11.56 \pm 0.36 a$ \\
\hline SBD $\left(\mathrm{g} . \mathrm{cm}^{-3}\right)$ & $1.21 \pm 0.01 a$ & $1.18 \pm 0.01 b$ & $1.16 \pm 0.01 b$ \\
\hline Clay (\%) & $19.12 \pm 0.42 b$ & $20.79 \pm 0.51 a$ & $21.84 \pm 0.42 a$ \\
\hline $\mathrm{pH}$ & $8.35 \pm 0.01 a$ & $8.32 \pm 0.02 a$ & $8.30 \pm 0.03 a$ \\
\hline $\operatorname{soc}\left(\mathrm{g} \cdot \mathrm{kg}^{-1}\right)$ & $6.18 \pm 0.17 c$ & $7.10 \pm 0.33 b$ & $7.28 \pm 0.24 a$ \\
\hline STN $\left(\mathrm{g} \cdot \mathrm{kg}^{-1}\right)$ & $0.54 \pm 0.03 b$ & $0.63 \pm 0.01 a$ & $0.67 \pm 0.03 a$ \\
\hline STP $\left(\mathrm{g} \cdot \mathrm{kg}^{-1}\right)$ & $0.44 \pm 0.01 a$ & $0.45 \pm 0.01 a$ & $0.45 \pm 0.01 a$ \\
\hline $\mathrm{DOC}\left(\mathrm{mg} \cdot \mathrm{kg}^{-1}\right)$ & $97.56 \pm 3.94 c$ & $171.14 \pm 4.87 b$ & $197.81 \pm 3.90 a$ \\
\hline SAN $\left(\mathrm{mg} \cdot \mathrm{kg}^{-1}\right)$ & $1.70 \pm 0.02 b$ & $1.65 \pm 0.02 b$ & $2.08 \pm 0.01 a$ \\
\hline SNN (mg.kg $\left.{ }^{-1}\right)$ & $10.26 \pm 0.22 b$ & $11.53 \pm 0.32 a$ & $12.00 \pm 0.13 a$ \\
\hline $\operatorname{SAP}\left(\mathrm{mg} \cdot \mathrm{kg}^{-1}\right)$ & $4.71 \pm 0.03 a$ & $4.60 \pm 0.01 a$ & $4.60 \pm 0.12 a$ \\
\hline \multicolumn{4}{|c|}{$\begin{array}{l}\text { The values are mean } \pm \text { standard error. Different letters indicate significant differences }(p<0.05) \\
\text { among different land use types based on a one-way ANOVA followed by an LSD test. SWC: soil water } \\
\text { content; SBD: soil bulk density; SOC: soil organic carbon; STN: soil total nitrogen; STP: soil total } \\
\text { phosphorus; DOC: soil dissolved organic carbon; SAN: soil ammonia nitrogen; SNN: soil nitrate } \\
\text { nitrogen; SAP: soil available phosphorus; GL: grassland; SF: Caragana korshinskii; MF: Robinia } \\
\text { pseudoacacia. }\end{array}$} \\
\hline
\end{tabular}

\section{Variation In Microbial Indexes}

\section{Soil Microbial Biomass and Enzyme Activities}

Soil microbial biomass and enzyme activities significantly differed among different secondary succession patterns (Table 4). Compared with GL, MBC, MBN, MBP, BG, NAG + LAP, and ALP increased by $2.22,2.02,1.26,1.15,0.94$, and 1.76 times after the artificial secondary succession, respectively, and those of MF were the largest. In addition, MBC, MBN, and ALP showed significant differences between grassland and afforestation. Notably, the NAG + LAP value was the lowest in SF than GL and MF. 
Table 4

The soil microbial biomass and enzyme activity in the three land types.

\begin{tabular}{|c|c|c|c|c|c|c|}
\hline $\begin{array}{l}\text { Land } \\
\text { types }\end{array}$ & $\begin{array}{l}\text { MBC } \\
\left(\mathrm{mg} \cdot \mathrm{kg}^{-1}\right)\end{array}$ & $\begin{array}{l}\text { MBN } \\
\left(\mathrm{mg}^{\mathrm{kg}}{ }^{-1}\right)\end{array}$ & $\begin{array}{l}\text { MBP } \\
\left(\mathrm{mg} \cdot \mathrm{kg}^{-1}\right)\end{array}$ & $\begin{array}{l}\text { BG } \\
\left(\mathrm{nmol} . \mathrm{g}^{-}\right. \\
\left.{ }^{1} \cdot \mathrm{h}^{-1}\right)\end{array}$ & $\begin{array}{l}\text { NAG + LAP } \\
\left(\mathrm{nmol} \cdot \mathrm{g}^{-}\right. \\
\left.{ }^{1} \cdot \mathrm{h}^{-1}\right)\end{array}$ & $\begin{array}{l}\text { ALP } \\
\left(\mathrm{nmol} . \mathrm{g}^{-}\right. \\
\left.{ }^{1} \cdot \mathrm{h}^{-1}\right)\end{array}$ \\
\hline GL & $\begin{array}{l}157.57 \pm \\
6.33 c\end{array}$ & $\begin{array}{l}28.26 \pm \\
1.53 c\end{array}$ & $\begin{array}{l}8.60 \pm \\
0.31 b\end{array}$ & $\begin{array}{l}30.47 \pm \\
0.93 \mathrm{~b}\end{array}$ & $\begin{array}{l}80.63 \pm \\
2.96 a\end{array}$ & $\begin{array}{l}72.28 \pm \\
1.36 \mathrm{c}\end{array}$ \\
\hline SF & $\begin{array}{l}248.56 \pm \\
5.21 \mathrm{~b}\end{array}$ & $\begin{array}{l}43.15 \pm \\
0.87 b \mathrm{~b}\end{array}$ & $\begin{array}{l}9.80 \pm \\
0.35 \mathrm{~b}\end{array}$ & $\begin{array}{l}29.11 \pm \\
0.52 \mathrm{~b}\end{array}$ & $\begin{array}{l}66.80 \pm \\
1.65 \mathrm{~b}\end{array}$ & $\begin{array}{l}87.91 \pm \\
1.32 \mathrm{~b}\end{array}$ \\
\hline MF & $\begin{array}{l}449.10 \pm \\
2.51 a\end{array}$ & $\begin{array}{l}71.15 \pm \\
0.78 \mathrm{a}\end{array}$ & $\begin{array}{l}11.87 \pm \\
0.35 a\end{array}$ & $\begin{array}{l}41.19 \pm \\
0.55 a\end{array}$ & $\begin{array}{l}84.48 \pm \\
3.08 \mathrm{a}\end{array}$ & $\begin{array}{l}166.74 \pm \\
3.18 a\end{array}$ \\
\hline
\end{tabular}

\section{Diversity And Composition Of Microbial Communities}

The $H_{\text {Bacteria }}$ was the lowest at GL and then increased at SF with a maximum of 7.36 at MF (Fig. 1a). The $S_{\text {Bacteria }}$ of GL, SF, and MF were $2.52 \times 10^{3}, 2.98 \times 10^{3}$, and $3.33 \times 10^{3}$, respectively. Compared with MF, $S_{\text {Fungi }}$ decreased by 11.72 and $10.15 \%$ at GL and SF, respectively (Fig. 1 b).

The soil bacteria was dominated by Actinobacteria (29.76\%) and Acidobacteria (22.42\%), followed by Proteobacteria (20.39\%), Chloroflexi (11.94\%), Gemmatimonadetes (8.87\%), and Nitrospirae (2.86\%) (Fig. 2a). The relative abundance of Actinobacteria was the highest in the GL than the SF and MF. The relative abundance of Proteobacteria was greatest in MF compared to the other three land uses. However, the relative abundance of Acidobacteria showed different changes, and that of SF (26.59\%) was higher relative to GL (19.67\%) and MF (21.01\%). In addition, Ascomycota (40.11\%), Basidiomycota (17.09\%), Zygomycota (6.64\%), and Cercozoa (1.09\%) dominated the fungal community composition in all sites (Fig. 2b). Compared with GL, the relative abundance of Ascomycota increased by 1.60 and 1.70 times in SF and MF, respectively. The relative abundance of Basidiomycota decreased significantly from GL to MF. The relative abundances of Zygomycota, and Cercozoa were higher in MF compared to those in the other land uses.

The PCA method, employed to assess the variations in community composition and structure among the sites, and soil microbial communities differ significantly at each land use (Fig. 3 ). The analysis reinforces the view that the soil bacterial and fungal communities were significantly different from each other at the sites of the three land uses. 
Plant characteristics significantly affected the diversity of soil bacteria (Figs. 4 and 5). The LB and FRB were significantly positively correlated with $S_{\text {Plant }}$ soil microbial biomass (MBC, MBN, and MBP), and enzyme activity (BG and ALP) (Fig. 4 and S2). LB and FRB were significantly positively correlated with Proteobacteria, Zygomycota and Cercozoa, while negatively correlated with Actinobacteria and Basidiomycota (Fig. 5).

Soil properties have important effects on the diversity and composition of soil microorganisms (Figs. 4 and 5). $S_{\text {Fungi }}$ soil microbial biomass, and enzyme activity were significantly positively correlated with SW, SOC, STN, DOC, and SNN, and negatively correlated with SBD and SAP (Figs. 4 and S2). However, $H_{B a c t e r i a}$ reversed. In addition, Acidobacteria showed significant negative correlation with SW, Clay, SOC, STN, STP, DOC, SAN, and SNN, and positive correlation with SBD, pH, and SAP, but Proteobacteria and Nitrospirae were reversed (Fig. 5). DOC and SAN were significantly negatively correlated with Basidiomycota and positively correlated with Zygomycota and Cercozoa.

The responses of soil bacterial and fungal communities to plant characteristics and soil properties were heterogeneous (Figs. 6 and 7). The contributions of plant and soil can explain $76.95 \%$ of soil bacterial diversity and $90.64 \%$ of bacterial composition (Figs. 6 a and 7a), in which the effect of plant characteristics on diversity was more intense. The relative effects of $\mathrm{HB}, \mathrm{HC}, S_{\text {Plant }}$ and $H_{\text {Plant }}$ on the diversity of soil bacteria were $10.84,10.43,10.30$, and $10.19 \%$, respectively, which were more significant than other variables (Fig. 6a). The contributions of plant and soil can explain $88.14 \%$ of the diversity of soil fungi and $71.39 \%$ of the composition of fungi (Figs. 6b, 7b). The effect of soil properties on composition was more obvious. The relative effects of LB, SAN, and SW on the composition of soil fungal communities were $6.71,6.41$, and $6.25 \%$, respectively, which were more significant than other variables (Fig. 7b). According to the PLS-PM, we found that restoration patterns significantly regulated plant characteristics (HC, HB, LB, and FRB) and soil properties (SW, pH, SOC, STN, and SNN) (Fig. 8). Notably, soil properties significantly affected the diversity of soil bacterial and fungal communities, and plant characteristics were closely related to the dominant phyla of soil microbial communities.

\section{Discussion}

There were obvious differences in vegetation characteristics and soil properties under different vegetation restoration patterns (Tables 2 and 3). Simultaneously, there may be strong differences in the sensitivity of soil bacterial and fungal communities to environmental factors. We hypothesized that the diversity and composition of soil bacterial and fungal communities were heterogeneous in response to changes in plant and soil factors. Therefore, we explored the relationship between vegetation and soil variables and soil microbial diversity and composition under different restoration patterns, which provided a framework for revealing the succession mechanism of soil bacterial and fungal communities.

\section{Effects Of Vegetation Characteristic Variables On Soil Microbial Properties}


In this study, litter and fine root biomass significantly affected the diversity of soil bacterial communities, which confirmed our first hypothesis. Simultaneously, the effects of HB, HC, $S_{\text {Plant }}$ and $H_{\text {Plant }}$ on the diversity of soil bacteria were more significant than other variables (Fig. 6a). These results were consistent with the findings by Zhang et al. [1] who observed that plant diversity was significantly correlated with the diversity of bacterial communities. The correlations may be attributed to the fact that the increase of vegetation communities in secondary succession accelerated litter and rhizo-deposits adequate $\mathrm{C}$ resources and nutrients for microbial growth [8]. Litter decomposition and root exudates provide energy and nutrient sources for the soil community and improve soil alkaline environment caused by organic acids and humic acids for soil microbial growth [31]. Furthermore, with greater quantity and quality of litter materials and fine root, afforestation generates more organic matter and other resources for soil microbes than grassland (Table 2), leading to more abundant decomposers and supporting a more biodiverse microbial community [32,33]. In addition, we found that LB and FRB were significantly positively correlated with soil microbial biomass, and enzyme activity (Fig. S2). Previous studies showed that the soil microbial biomass, $\mathrm{C}, \mathrm{N}$, and $\mathrm{P}$ acquisition enzymes are significantly higher in vegetations with greater biomass of root systems [34, 35]. And Peng and Wang [36] revealed that extracellular enzymes reflected nutrient requirements of microorganisms and the supply of nutrients in the environment. However, we found interestingly that there was no significant relationship between soil fungal diversity and plant characteristics (Fig. 2). This discrepancy might be due to the deficiency of colinked environmental control factors and direct functional associations between plant and soil fungi in our survey region [31]. Therefore, plant characteristics could explain differences in the diversity of soil bacterial communities under different vegetation succession patterns.

Our study found that LB and FRB were significantly positively correlated with Proteobacteria, Zygomycota and Cercozoa, but negatively correlated with Actinobacteria and Basidiomycota (Fig. 5). Simultaneously, the effect of LB on the composition of soil fungi was most significant than other variables (Fig. 6a). Litter decomposition and root exudates provide $\mathrm{C}$ resources and nutrients for soil microorganisms, which modulate the composition and growth of soil microbial communities [10]. Some studies have demonstrated that bacteria communities are associated with soil carbon and nitrogen cycling [22]. And Proteobacteria is commonly used as copiotrophic bacteria, due to its extracellular membrane consists of lipopolysaccharide that was involved in carbon conversion [37]. Metabolism in Actinobacteria was affected by light intensity, and the increase in above-ground biomass from grassland to forestland weakens their metabolic efficiencies (Table 2; [38]). Considering the $\mathrm{N}_{2}$-fixing capacity of leguminous plants such as Robinia pseudoacacia and Caragana korshinskii, the combination of $\mathrm{N}_{2}$-fixing microorganisms and mycorrhizas was stronger [22]. In addition, some studies have confirmed that soil fungal communities are modulated by rotten detritus, litter and rhizosphere [24]. Previous studies identified that strains of Zygomycota are involved in symbiotic mycorrhizas with plants and aid in the decomposition of plant residues and litter [31]. In contrast, overly dense herbs and litter may inhibit the growth of Basidiomycota [39, 40]. Furthermore, the significant correlation between vegetation characteristics (LB and FRB) and the abundance of dominant phyla of soil bacteria and fungi emphasized that plant biomass plays an important role in the succession of microorganisms [8]. And 
plant characteristics differentially affect the composition and growth of soil microbial communities mainly through litter and rhizosphere pathways.

\section{Effects Of Soil Variables On Soil Microbial Properties}

The development of plant community is fundamental for soil restoration, and it strongly influences the dynamics of soil physicochemical properties [41]. Furthermore, changes in microbial community diversity are sensitive to changes of soil environment, such as changes in soil moisture, density, and nutrients [1]. This study observed the effects of soil properties on the diversity of soil bacteria after afforestation, we found that $S_{\text {Fungi }}$ and microbial biomass were significantly positively correlated with SW, SOC, STN, DOC, and SNN, and negatively correlated with SBD and SAP (Figs. 4 and S2). And soil fungal diversity and soil nutrients in afforestation were higher than in cultivated soil (Table 3 and Fig. 1). In the same area, Ren et al. [22] have revealed that the increase in organic input from litters and rhizomes promoted the utilization of $\mathrm{C}$ resources and nutrients by microorganisms. In generally, a loose soil environment created by afforestation increases the total porosity, aeration, and decomposition of roots is conducive to improving microbial metabolism and diversity $[42,43]$. Thus, the increase in soil fungal diversity and biomass were consistent with the decrease in bulk density among vegetation restoration. Moreover, microbial community diversity and biomass with vegetation restoration were influenced by soil nitrate nitrogen, which is considered as the preferred source of $\mathrm{N}$ for microbes $[44,45]$. And the increase of nitrate nitrogen after afforestation is paralleled by the accumulation of $\mathrm{H}^{+}$(Table 3; [46]). In addition, soil moisture is an important factor driving changes in soil microbial respiration and soil nutrients, which can affect soil microbial communities [47]. Furthermore, the growth rate hypothesis emphasizes that the growth of soil microbes is related to the need for $\mathrm{P}$ for $\mathrm{r}$-RNA synthesis, prompting the microbial community to enter soil [22]. However, the low SAP observed may limit the absorption of phosphorus by microbes [8]. In contrast, the correlation between soil bacterial diversity and soil properties was inconsistent with fungi (Fig. 4). This result may be related to excessive Acidobacteria in farmland [1]. Allison and Vitousek [48] found that soil ALP activity was inversely related to soil $\mathrm{P}$ availability, and soil nitrogen cycling can promote the increase of NAG and LAP activities. Given that the correlation between soil microbial biomass and soil properties was consistent with extracellular enzymes involved in organic matter decomposition in forest soils, which may be attributed to any modification of environmental factors to the microbial community can be reflected in the level of enzyme activities (C-acquiring, N-acquiring, and P-acquiring enzymes) [25, 49].

We found that the composition of soil bacterial and fungal communities responded differently to soil factors (Figs. 5, 7 and 8). Our results showed that Acidobacteria was significant negative correlation with SW, Clay, SOC, STN, STP, DOC, SAN, and SNN, and positive correlation with SBD, pH, and SAP, but Proteobacteria and Nitrospirae were reversed (Fig. 5). Copiotroph and oligotroph were often regarded as a measure about soil environment of ecosystems $[8,12]$. Proteobacteria associated with the enrichment of carbon pool is regarded as copiotrophs [12]. Therefore, increases in the abundance of Proteobacterial flora can promote the accumulation of soil nitrogen. Conversely, Acidobacteria may be richer in nutrientpoor soil environments and likely act as oligotrophs [1]. And the reduction of soil pH provides an optimal 
living environment for microorganisms, which was conducive to the use of soil carbon resources and nutrients by copiotrophs [8]. Moreover, Nitrospirales was positively correlated with STN, SAN, and SNN, implying that Nitrospirales oxidizes ammonium to nitrate through nitrification, and the suitable air tightness of soil improves the metabolism of nitrobacteria in different restoration patterns $[8,12]$. Soil moisture was an important factor in semiarid regions, which strongly affects soil microbial communities [37]. After afforestation, the increase of soil moisture enhances microbial activity, but also intensifies the leaching of soil phosphorus and reduces the use of SAP [42]. In addition, DOC and SAN were significantly negatively correlated with Basidiomycota and positively correlated with Zygomycota and Cercozoa (Fig. 5). Prescott et al. [10] found that soil carbon and nitrogen dynamics can affect fungal community composition because Basidiomycota metabolize the organic substrates of rhizodeposition. The abundance of Zygomycota decreased significantly with afforestation, which is inconsistent with Liu 's [12] conclusions, revealing that Zygomycota is linked to litter biomass and soil nutrients. This result may be attributed to indirect interference from other environmental factors in this area [11]. Furthermore, the regulation of soil microbial diversity by soil properties emphasized that dominant species of soil bacteria and fungi accumulate in nutrient -rich environments.

\section{Conclusions}

Altogether, these results indicated that plant characteristics and soil factors were significantly varied under different vegetation restoration patterns. And the results of this study provide evidence for differences in soil microbial communities in different vegetation restoration. The relative contribution of vegetation and soil to bacterial and fungal communities illustrated that plant characteristics and soil properties may synergistically modulate the diversity and composition of soil microbial communities. And soil bacterial and fungal communities mainly depend on plant biomass and soil nutrients. Overall, this study provides important guidance for the vegetation restoration patterns in the ecologically fragile areas of the Loess Plateau.

\section{Declarations}

\section{Acknowledgments}

National Natural Science Foundation of China (No. 41877543) financially supported this work.

\section{Declarations:}

Funding Information National Natural Science Foundation of China (No. 41877543).

Conflicts of Interest The authors declare that they have no known competing financial interests or personal relationships that could have appeared to influence the work reported in this paper.

Data Availability Some or all data, models, or code generated or used during the study are available from the corresponding author by request. 
Authors' Contributions: MPX, XHH and JYW conceived and designed the experiments; MPX and CJR performed the experiments and processed the samples; MPX wrote a first version of the manuscript, and MPX and GHY substantially contributed to the last version of the manuscript.

\section{Acknowledgments}

National Natural Science Foundation of China (No. 41877543) financially supported this work.

\section{References}

1. Zhang C, Liu G, Xue S, Wang G (2016) Soil bacterial community dynamics reflect changes in plant community and soil properties during the secondary succession of abandoned farmland in the Loess Plateau. Soil Biology \& Biochemistry 97: 40-49. doi: 10.1016/j.soilbio.2016.02.013

2. Zhong Z, Wang X, Zhang X, Zhang W, Xu Y, Ren C, Han X, Yang G (2019) Edaphic factors but not plant characteristics mainly alter soil microbial properties along a restoration chronosequence of Pinus tabulaeformis stands on Mt. Ziwuling, China. Forest Ecology and Management 453. doi: 10.1016/j.foreco.2019.117625

3. Wu X, Xu H, Tuo D, Wang C, Fu B, Lv Y, Liu G (2020) Land use change and stand age regulate soil respiration by influencing soil substrate supply and microbial community. Geoderma 359. doi: 10.1016/j.geoderma.2019.113991

4. Blagodatskaya E, Kuzyakov Y (2008) Mechanisms of real and apparent priming effects and their dependence on soil microbial biomass and community structure: critical review. Biology and Fertility of Soils 45: 115-131. doi: 10.1007/s00374-008-0334-y

5. Brockett BFT, Prescott CE, Grayston SJ (2012) Soil moisture is the major factor influencing microbial community structure and enzyme activities across seven biogeoclimatic zones in western Canada. Soil Biology \& Biochemistry 44: 9-20. doi: 10.1016/j.soilbio.2011.09.003

6. Ren C, Zhang W, Zhong Z, Han X, Yang G, Feng Y, Ren G (2018) Differential responses of soil microbial biomass, diversity, and compositions to altitudinal gradients depend on plant and soil characteristics. Science of the Total Environment 610: 750-758. doi: 10.1016/j.scitotenv.2017.08.110

7. van der Heijden MGA, Bardgett RD, van Straalen NM (2008) The unseen majority: soil microbes as drivers of plant diversity and productivity in terrestrial ecosystems. Ecology Letters 11: 296-310. doi: 10.1111/j.1461-0248.2007.01139.x

8. Xu M, Lu X, Xu Y, Zhong Z, Zhang W, Ren C, Han X, Yang G, Feng Y (2020) Dynamics of bacterial community in litter and soil along a chronosequence of Robinia pseudoacacia plantations. Science of the Total Environment 703. doi: 10.1016/j.scitotenv.2019.135613

9. Drenovsky RE, Steenwerth KL, Jackson LE, Scow KM (2010) Land use and climatic factors structure regional patterns in soil microbial communities. Global Ecology and Biogeography 19: 27-39. doi: 10.1111/j.1466-8238.2009.00486.x 
10. Prescott CE, Grayston SJ (2013) Tree species influence on microbial communities in litter and soil: Current knowledge and research needs. Forest Ecology and Management 309: 19-27. doi: 10.1016/j.foreco.2013.02.034

11. Yang $Y$, Cheng H, Dou Y, An S (2020) Plant and soil traits driving soil fungal community due to tree plantation on the Loess Plateau. Science of the Total Environment 708. doi:

10.1016/j.scitotenv.2019.134560

12. Liu J, Yang Z, Dang P, Zhu H, Gao Y, Vu Ngoc H, Zhao Z (2018) Response of soil microbial community dynamics to Robinia pseudoacacia L. afforestation in the loess plateau: a chronosequence approach. Plant and Soil 423: 327-338. doi: 10.1007/s11104-017-3516-2

13. Reinhart KO, Dangi SR, Vermeire LT (2016) The effect of fire intensity, nutrients, soil microbes, and spatial distance on grassland productivity. Plant and Soil 409: 203-216. doi: 10.1007/s11104-0162957-3

14. Carrino-Kyker SR, Kluber LA, Petersen SM, Coyle KP, Hewins CR, DeForest JL, Smemo KA, Burke DJ (2016) Mycorrhizal fungal communities respond to experimental elevation of soil pH and $\mathrm{P}$ availability in temperate hardwood forests. Fems Microbiology Ecology 92. doi:

10.1093/femsec/fiw024

15. Holste EK, Kobe RK (2017) Tree species and soil nutrients drive tropical reforestation more than associations with mycorrhizal fungi. Plant and Soil 410: 283-297. doi: 10.1007/s11104-016-3013-z

16. Zhou Z, Wang C, Luo Y (2018) Effects of forest degradation on microbial communities and soil carbon cycling: A global meta-analysis. Global Ecology and Biogeography 27: 110-124. doi: 10.1111/geb. 12663

17. Gebhardt M, Fehmi JS, Rasmussen C, Gallery RE (2017) Soil amendments alter plant biomass and soil microbial activity in a semi-desert grassland. Plant and Soil 419: 53-70. doi: 10.1007/s11104017-3327-5

18. Li S, Shakoor A, Wubet T, Zhang N, Liang Y, Ma K (2018) Fine-scale variations of fungal community in a heterogeneous grassland in Inner Mongolia: Effects of the plant community and edaphic parameters. Soil Biology \& Biochemistry 122: 104-110. doi: 10.1016/j.soilbio.2018.04.007

19. Zhang W, Xu Y, Gao D, Wang X, Liu W, Deng J, Han X, Yang G, Feng Y, Ren G (2019) Ecoenzymatic stoichiometry and nutrient dynamics along a revegetation chronosequence in the soils of abandoned land and Robinia pseudoacacia plantation on the Loess Plateau, China. Soil Biology \& Biochemistry 134: 1-14. doi: 10.1016/j.soilblo.2019.03.017

20. Ren C, Zhao F, Shi Z, Chen J, Han X, Yang G, Feng Y, Ren G (2017) Differential responses of soil microbial biomass and carbon-degrading enzyme activities to altered precipitation. Soil Biology \& Biochemistry 115: 1-10. doi: 10.1016/j.soilbio.2017.08.002

21. Xu Y, Zhong Z, Zhang W, Han X, Yang G, Ren C, Feng Y, Ren G, Wang X (2019) Responses of soil nosZ-type denitrifying microbial communities to the various land-use types of the Loess Plateau, China. Soil \& Tillage Research 195. doi: 10.1016/j.still.2019.104378 
22. Ren C, Zhao F, Kang D, Yang G, Han X, Tong X, Feng Y, Ren G (2016) Linkages of C:N:P stoichiometry and bacterial community in soil following afforestation of former farmland. Forest Ecology and Management 376: 59-66. doi: 10.1016/j.foreco.2016.06.004

23. Zhao F, Zhang L, Ren C, Sun J, Han X, Yang G, Wang J (2016) Effect of microbial carbon, nitrogen, and phosphorus stoichiometry on soil carbon fractions under a black locust forest within the central Loess Plateau of China. Soil Science Society of America Journal 80: 1520-1530. doi: $10.2136 /$ sssaj2016.06.0175

24. Zhang C, Liu G, Xue S, Song Z (2011) Rhizosphere soil microbial activity under different vegetation types on the Loess Plateau, China. Geoderma 161: 115-125. doi: 10.1016/j.geoderma.2010.12.003

25. Liu X, Zhang $S$ (2019) Nitrogen addition shapes soil enzyme activity patterns by changing $\mathrm{pH}$ rather than the composition of the plant and microbial communities in an alpine meadow soil. Plant and Soil 440: 11-24. doi: 10.1007/s11104-019-04054-5

26. Zhang W, Ren C, Deng J, Zhao F, Yang G, Tong X, Feng Y, Han X (2018) Plant functional composition and species diversity affect soil $\mathrm{C}, \mathrm{N}$, and $\mathrm{P}$ during secondary succession of abandoned farmland on the Loess Plateau. Ecological Engineering 122: 91-99. doi: 10.1016/j.ecoleng.2018.07.031

27. Saiya-Cork KR, Sinsabaugh RL, Zak DR (2002) The effects of long term nitrogen deposition on extracellular enzyme activity in an Acer saccharum forest soil. Soil Biology \& Biochemistry 34: 13091315. doi: 10.1016/s0038-0717(02)00074-3

28. Xu Z, Yu G, Zhang X, He N, Wang Q, Wang S, Wang R, Zhao N, Jia Y, Wang C (2017) Soil enzyme activity and stoichiometry in forest ecosystems along the North-South Transect in eastern China (NSTEC). Soil Biology \& Biochemistry 104: 152-163. doi: 10.1016/j.soilbio.2016.10.020

29. Caporaso JG, Kuczynski J, Stombaugh J, Bittinger K, Bushman FD, Costello EK, Fierer N, Pena AG, Goodrich JK, Gordon JI, Huttley GA, Kelley ST, Knights D, Koenig JE, Ley RE, Lozupone CA, McDonald D, Muegge BD, Pirrung M, Reeder J, Sevinsky JR, Tumbaugh PJ, Walters WA, Widmann J, Yatsunenko T, Zaneveld J, Knight R (2010) QIIME allows analysis of high-throughput community sequencing data. Nature Methods 7: 335-336. doi: 10.1038/nmeth.f.303

30. Amann RI, Ludwig W, Schleifer KH (1995) Phylogenetic identification and in-situ detection of individual microbial-cells without cultivation. Microbiological Reviews 59: 143-169. doi: 10.1128/mmbr.59.1.143-169.1995

31. Xu L, Ravnskov S, Larsen J, Nilsson RH, Nicolaisen M (2012) Soil fungal community structure along a soil health gradient in pea fields examined using deep amplicon sequencing. Soil Biology \& Biochemistry 46: 26-32. doi: 10.1016/j.soilbio.2011.11.010

32. Meier E, Paal J, Liira J, Juriado I (2005) Influence of tree stand age and management on the species diversity in Estonian eutrophic alvar and boreo-nemoral Pinus sylvestris forests. Scandinavian Journal of Forest Research 20: 135-144. doi: 10.1080/14004080510042155

33. Zhang P, Li B, Wu J, Hu S (2019) Invasive plants differentially affect soil biota through litter and rhizosphere pathways: a meta-analysis. Ecology Letters 22: 200-210. doi: 10.1111/ele.13181 
34. Spohn M, Kuzyakov Y (2014) Spatial and temporal dynamics of hotspots of enzyme activity in soil as affected by living and dead roots-a soil zymography analysis. Plant and Soil 379: 67-77. doi: 10.1007/s11104-014-2041-9

35. Cui Y, Fang L, Guo X, Wang X, Zhang Y, Li P, Zhang X (2018) Ecoenzymatic stoichiometry and microbial nutrient limitation in rhizosphere soil in the arid area of the northern Loess Plateau, China. Soil Biology \& Biochemistry 116: 11-21. doi: 10.1016/j.soilbio.2017.09.025

36. Peng X, Wang W (2016) Stoichiometry of soil extracellular enzyme activity along a climatic transect in temperate grasslands of northern China. Soil Biology \& Biochemistry 98: 74-84. doi: 10.1016/j.soilbio.2016.04.008

37. Zhang F-G, Zhang Q-G (2016) Microbial diversity limits soil heterotrophic respiration and mitigates the respiration response to moisture increase. Soil Biology \& Biochemistry 98: 180-185. doi: 10.1016/j.soilbio.2016.04.017

38. Canals RM, Mugica L, Duran M, San Emeterio L (2019) Soil bacterial functional diversity mirrors the loss of plant diversity by the expansion of a native tall-grass in high mountain grasslands. Plant and Soil 445: 243-257. doi: 10.1007/s11104-019-04281-w

39. Uibopuu A, Moora M, Oepik M, Zobel M (2012) Temperate forest understorey species performance is altered by local arbuscular mycorrhizal fungal communities from stands of different successional stages. Plant and Soil 356: 331-339. doi: 10.1007/s11104-011-1116-0

40. Xiang X, Gibbons SM, Yang J, Kong J, Sun R, Chu H (2015) Arbuscular mycorrhizal fungal communities show low resistance and high resilience to wildfire disturbance. Plant and Soil 397: 347-356. doi: 10.1007/s11104-015-2633-z

41. Bauer JT, Blumenthal N, Miller AJ, Ferguson JK, Reynolds HL (2017) Effects of between-site variation in soil microbial communities and plant-soil feedbacks on the productivity and composition of plant communities. Journal of Applied Ecology 54: 1028-1039. doi: 10.1111/1365-2664.12937

42. Chen CR, Xu ZH, Blumfield TJ, Hughes JM (2003) Soil microbial biomass during the early establishment of hoop pine plantation: seasonal variation and impacts of site preparation. Forest Ecology and Management 186: 213-225. doi: 10.1016/s0378-1127(03)00275-5

43. Wang K, Zhang Y, Tang Z, Shangguan Z, Chang F, Jia Fa, Chen Y, He X, Shi W, Deng L (2019) Effects of grassland afforestation on structure and function of soil bacterial and fungal communities. Science of the Total Environment 676: 396-406. doi: 10.1016/j.scitotenv.2019.04.259

44. Merrick MJ, Edwards RA (1995) Nitrogen control in bacteria. Microbiological Reviews 59: 604-\&. doi: 10.1128/mmbr.59.4.604-622.1995

45. Marzluf GA (1997) Genetic regulation of nitrogen metabolism in the fungi. Microbiology and Molecular Biology Reviews 61: 17-+. doi: 10.1128/.61.1.17-32.1997

46. Barak P, Jobe BO, Krueger AR, Peterson LA, Laird DA (1997) Effects of long-term soil acidification due to nitrogen fertilizer inputs in Wisconsin. Plant and Soil 197: 61-69. doi: 10.1023/a:1004297607070

47. Drenovsky RE, Vo D, Graham KJ, Scow KM (2004) Soil water content and organic carbon availability are major determinants of soil microbial community composition. Microbial Ecology 48: 424-430. 
doi: $10.1007 / \mathrm{s} 00248-003-1063-2$

48. Allison SD, Vitousek PM (2005) Responses of extracellular enzymes to simple and complex nutrient inputs. Soil Biology \& Biochemistry 37: 937-944. doi: 10.1016/j.soilbio.2004.09.014

49. Kyaschenko J, Clemmensen KE, Hagenbo A, Karltun E, Lindahl BD (2017) Shift in fungal communities and associated enzyme activities along an age gradient of managed Pinus sylvestris stands. Isme Journal 11: 863-874. doi: 10.1038/ismej.2016.184

\section{Figures}
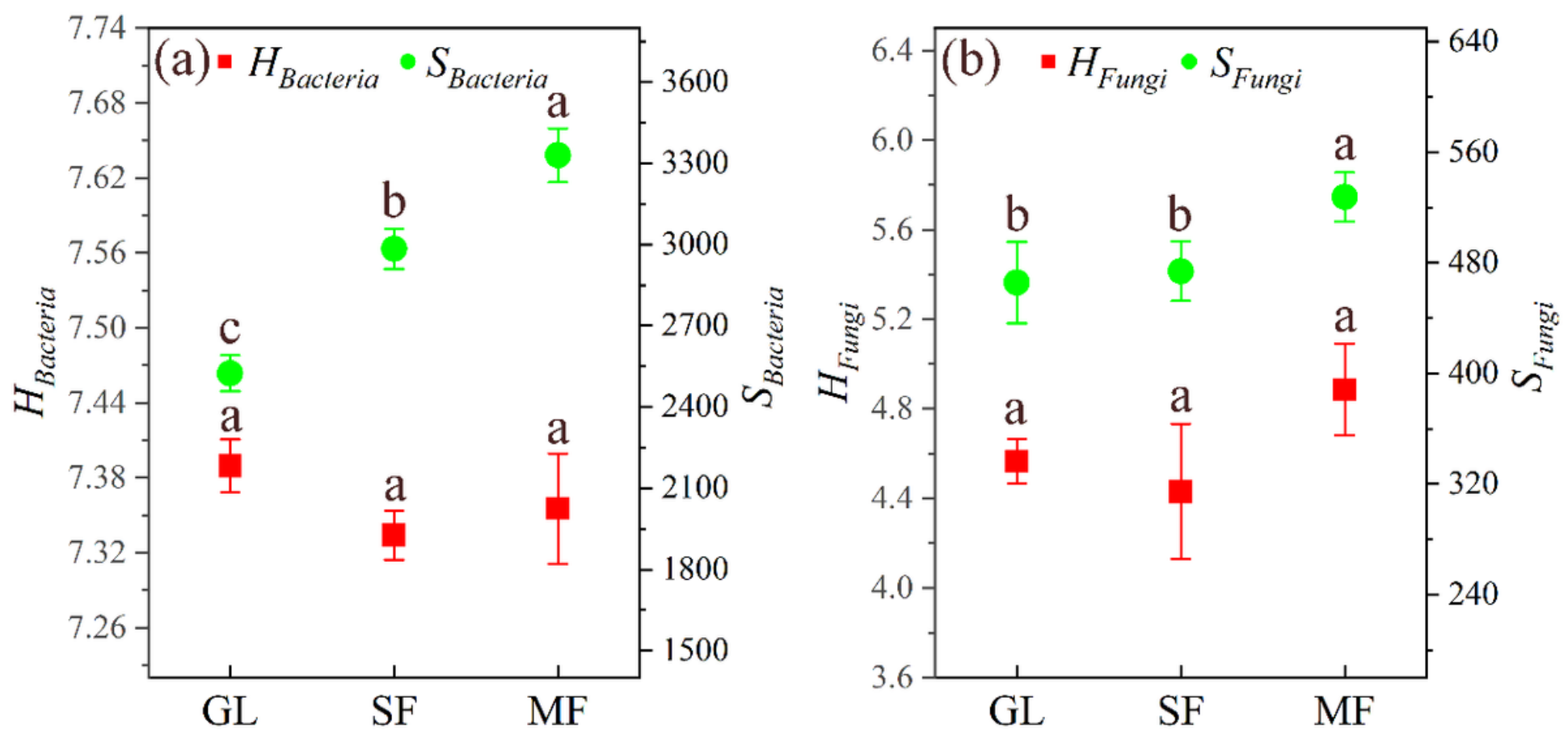

\section{Figure 1}

Diversity indices of bacterial and fungal community among the three land types. Different letters denote statistically significant differences among different land use types $(p<0.05)$. HBacteria and SBacteria: the Shannon and Chao index of soil bacteria; HFungi and SFungi: the Shannon and Chao index of soil fungi; GL: grassland; SF: Caragana korshinskii; MF: Robinia pseudoacacia. 

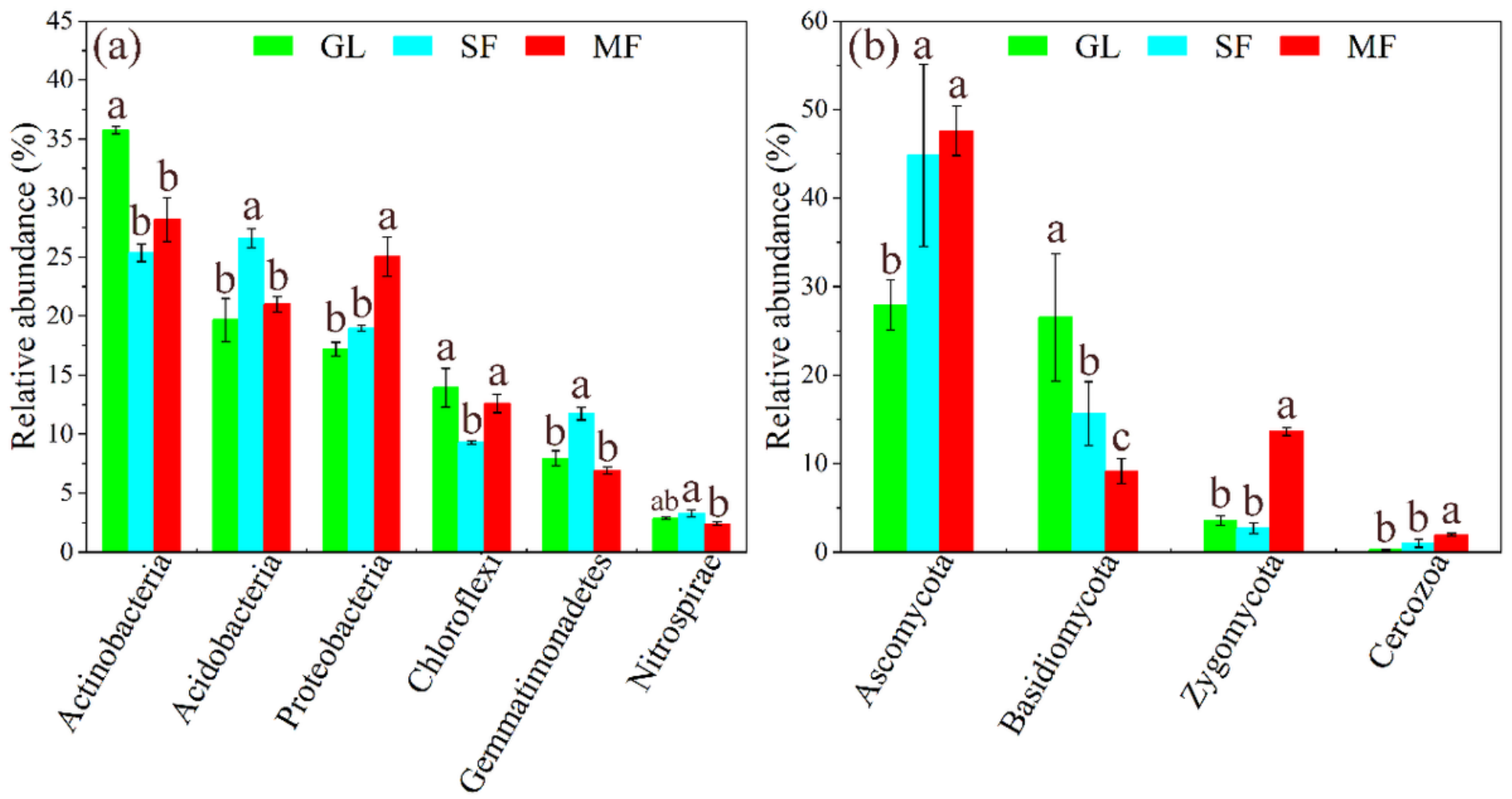

Figure 2

Relative abundance of the dominant groups of bacterial(a) and fungal(b) communities at the phylum level among the three land types. Different letters denote statistically significant differences among different land use types ( $\mathrm{p}<0.05)$. GL: grassland; SF: Caragana korshinskii; MF: Robinia pseudoacacia.

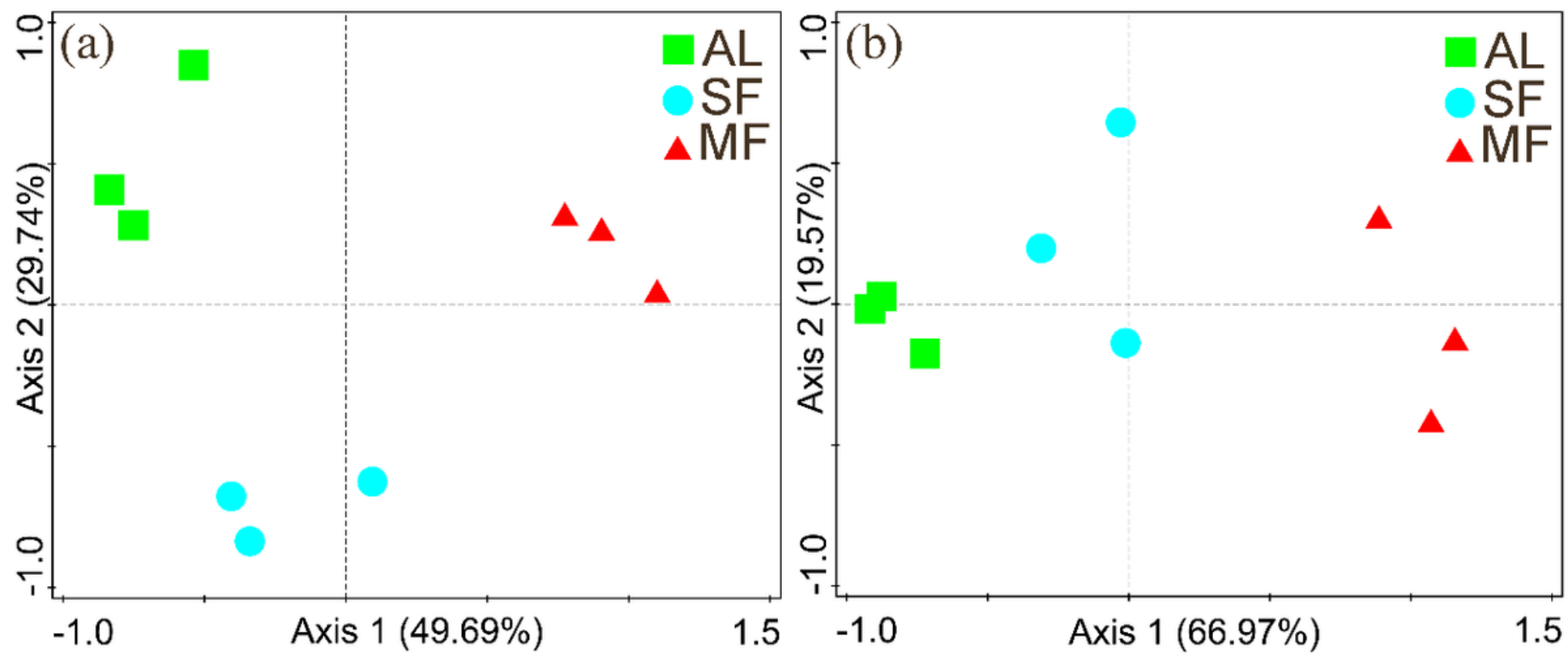

Figure 3

Principal component analysis (PCA) of bacterial (a) and fungal(b) community composition among the three land types. GL: grassland; SF: Caragana korshinskii; MF: Robinia pseudoacacia. 


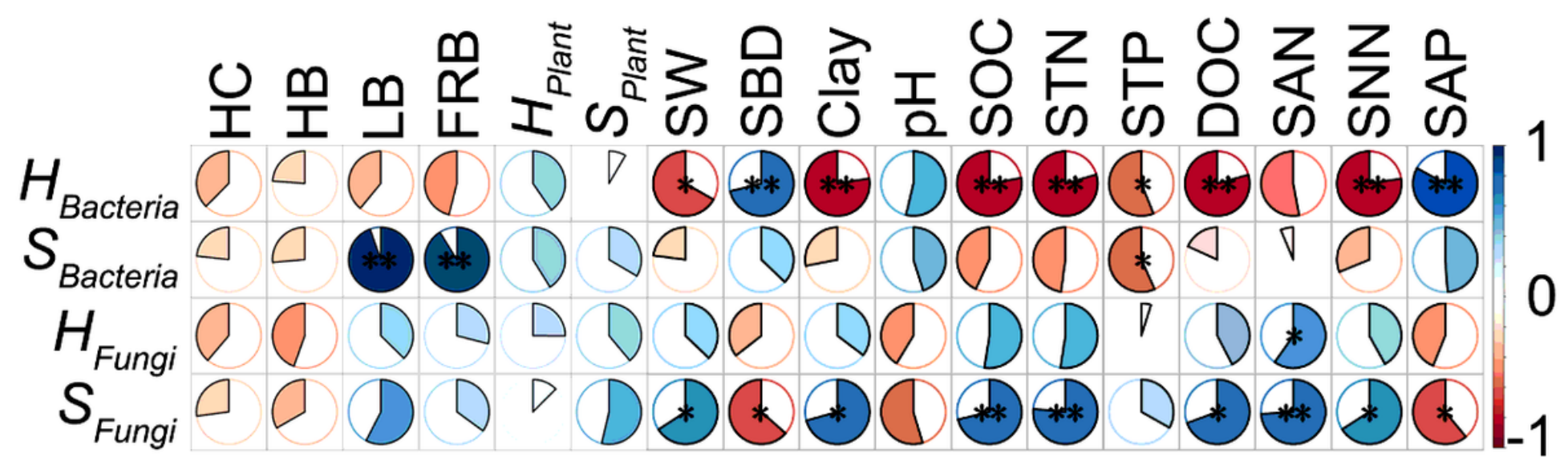

Figure 4

Spearman's rank correlation coefficient between the soil microbial diversity, and vegetation characteristics and soil physicochemical properties. ${ }^{*} \mathrm{P}<0.05,{ }^{\star}{ }^{*} \mathrm{P}<0.01$. HC: herb coverage; HB: herb biomass; LB: litter biomass; FRB: fine root biomass; SWC: soil water content; SBD: soil bulk density; SOC: soil organic carbon; STN: soil total nitrogen; STP: soil total phosphorus; DOC: soil dissolved organic carbon; SAN: soil ammonia nitrogen; SNN: soil nitrate nitrogen; SAP: soil available phosphorus; HPlant: Shannon-Wiener diversity index; SPlant: Margalef richness index.

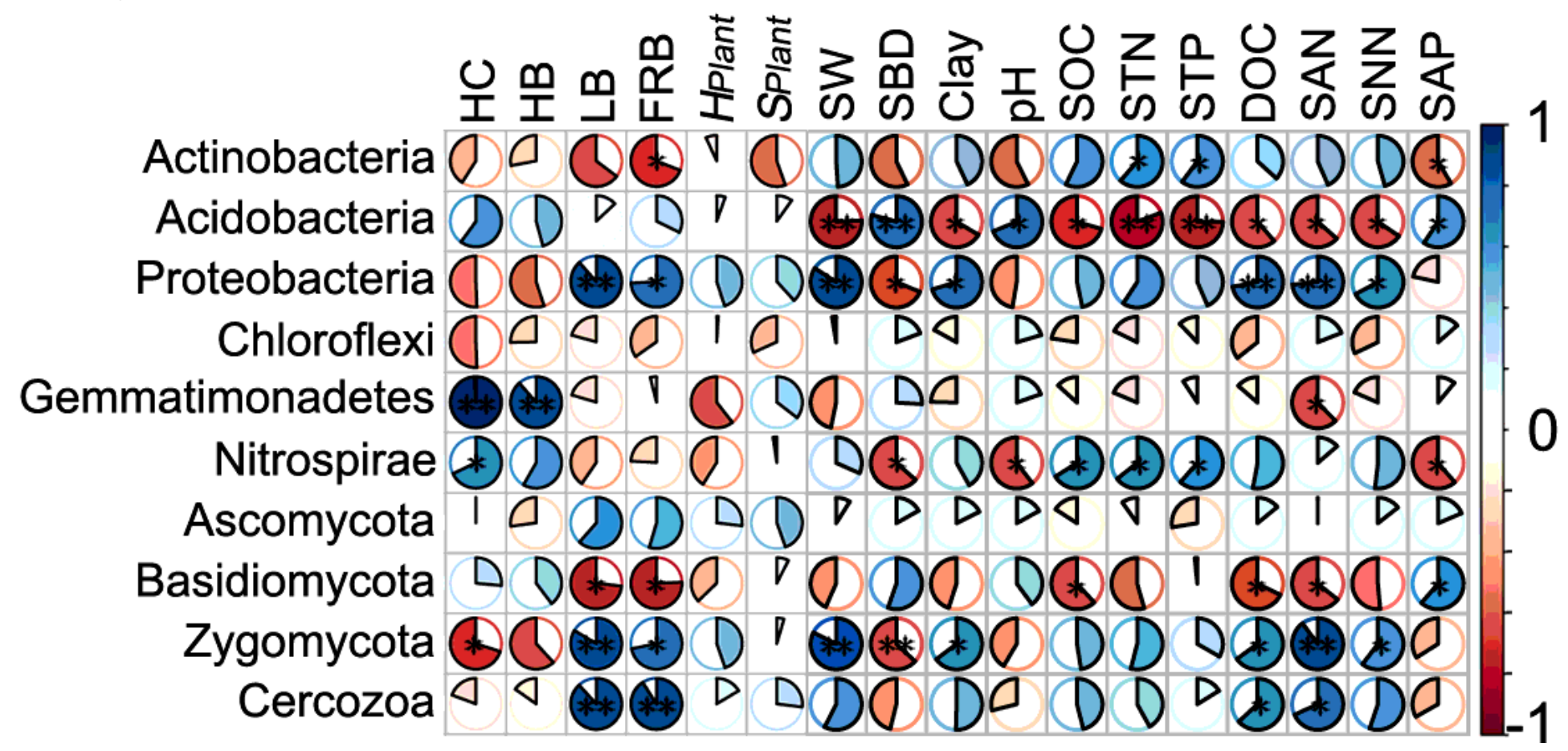

Figure 5

Spearman's rank correlation coefficient between the soil microbial community composition, and vegetation characteristics and soil physicochemical properties. ${ }^{*} \mathrm{P}<0.05,{ }^{*} \mathrm{P}<0.01$. HC: herb coverage; HB: herb biomass; LB: litter biomass; FRB: fine root biomass; SWC: soil water content; SBD: soil bulk density; SOC: soil organic carbon; STN: soil total nitrogen; STP: soil total phosphorus; DOC: soil dissolved organic carbon; SAN: soil ammonia nitrogen; SNN: soil nitrate nitrogen; SAP: soil available phosphorus. 

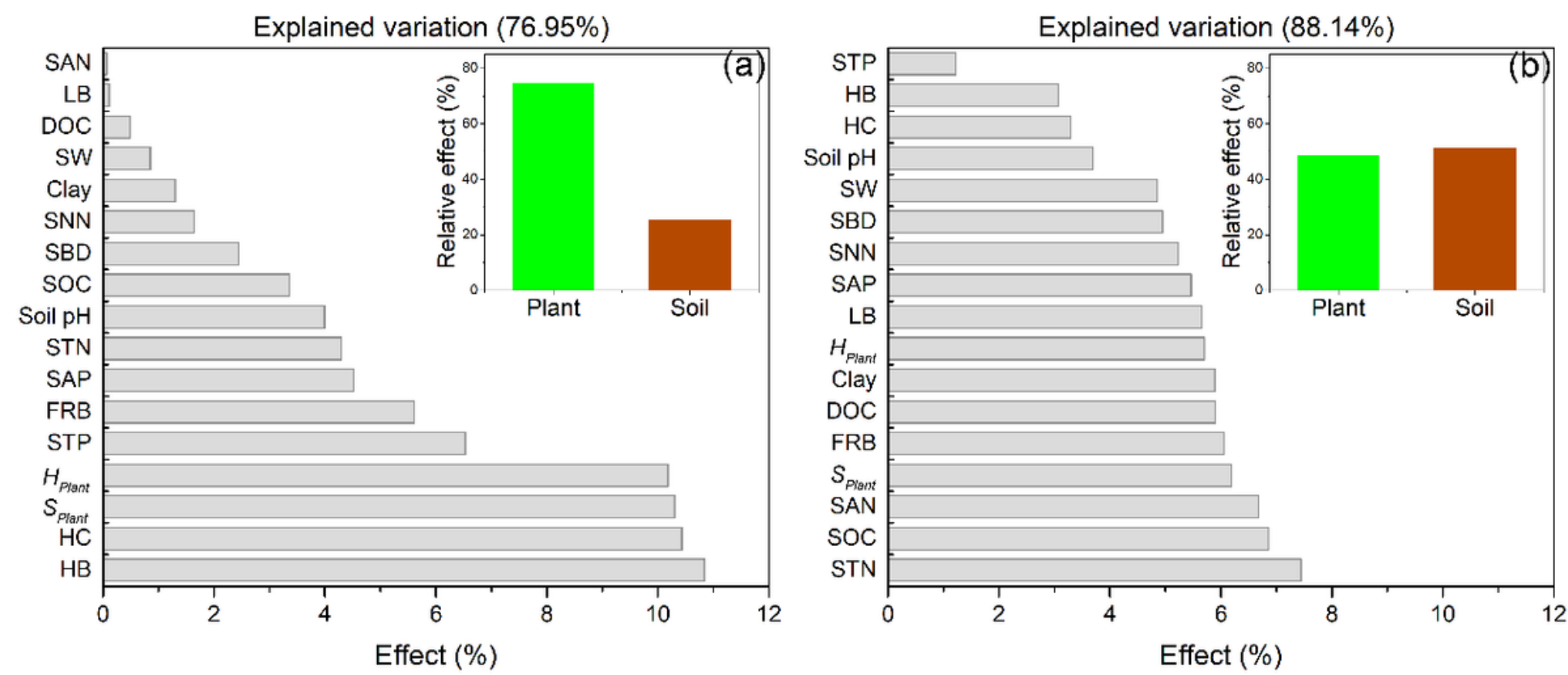

\section{Figure 6}

Effects of vegetation characteristics and soil physicochemical properties on the diversity of soil bacteria (a) and fungi (b). HC: herb coverage; HB: herb biomass; LB: litter biomass; FRB: fine root biomass; SWC: soil water content; SBD: soil bulk density; SOC: soil organic carbon; STN: soil total nitrogen; STP: soil total phosphorus; DOC: soil dissolved organic carbon; SAN: soil ammonia nitrogen; SNN: soil nitrate nitrogen; SAP: soil available phosphorus;
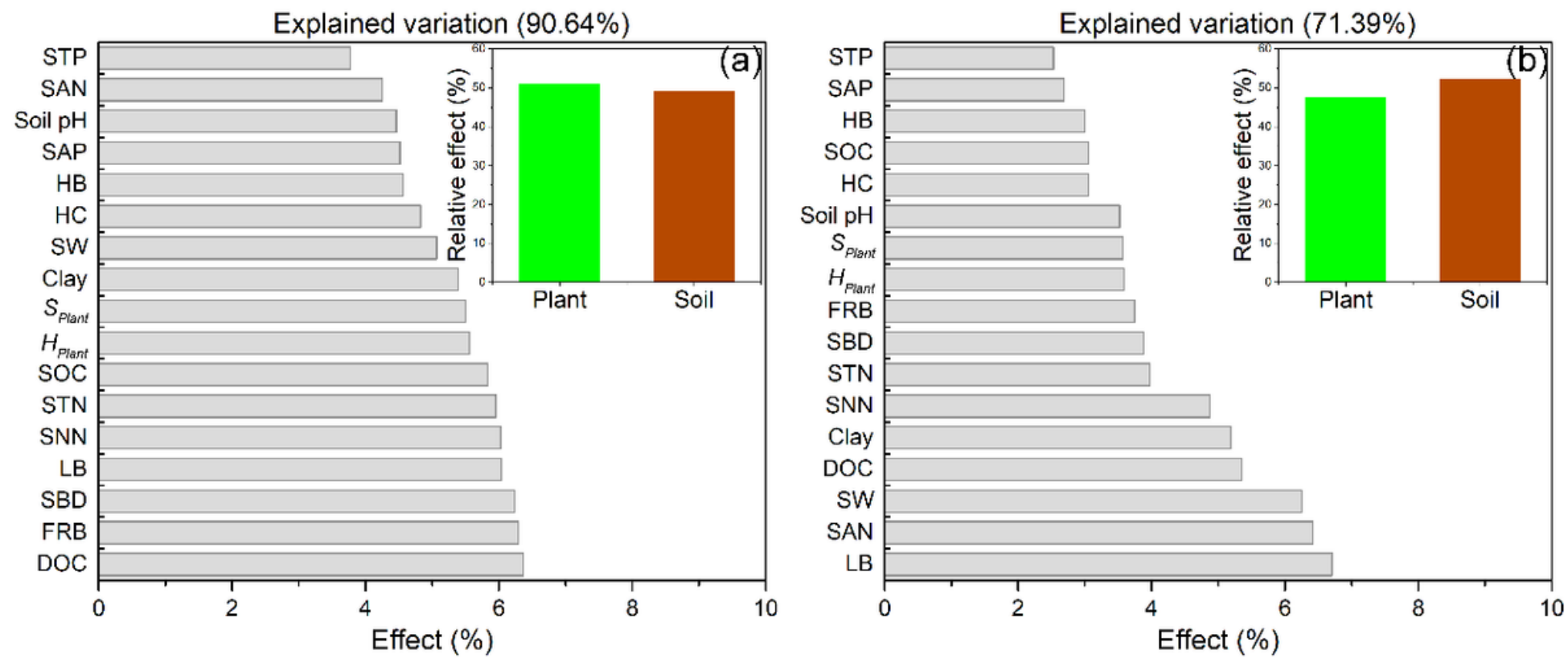

\section{Figure 7}

Effects of vegetation characteristics and soil physicochemical properties on the composition of soil bacteria (a) and fungi (b). HC: herb coverage; HB: herb biomass; LB: litter biomass; FRB: fine root biomass; SWC: soil water content; SBD: soil bulk density; SOC: soil organic carbon; STN: soil total 
nitrogen; STP: soil total phosphorus; DOC: soil dissolved organic carbon; SAN: soil ammonia nitrogen; SNN: soil nitrate nitrogen; SAP: soil available phosphorus;

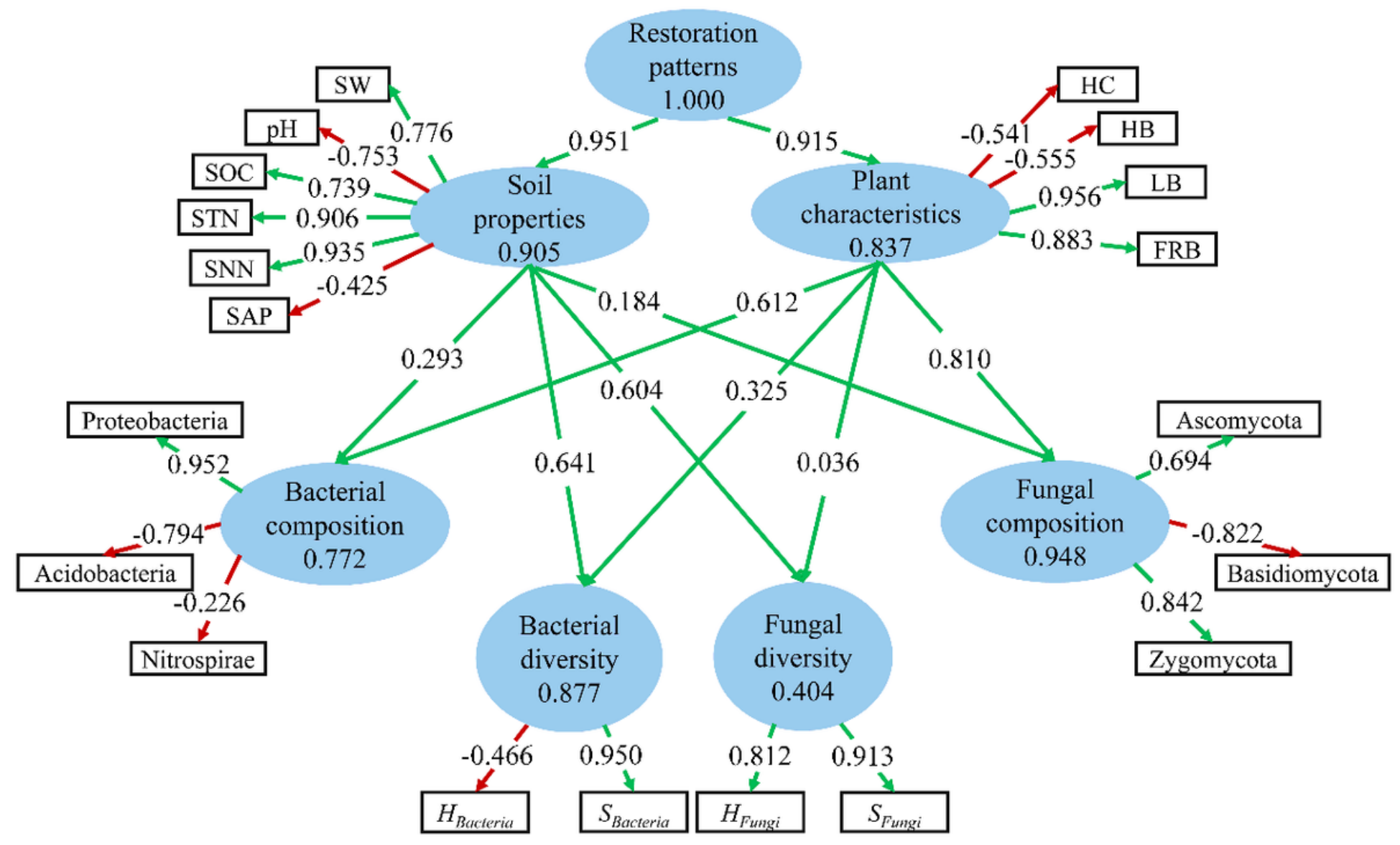

\section{Figure 8}

Partial least squares path models (PLS-PM) of the drivers of soil bacterial and fungal community. Path analysis results for direct and indirect effects of restoration patterns, soil properties and plant characteristics on the diversity and composition of soil bacterial and fungal community. Numbers on arrows are path coefficients indicating a positive (positive number) or negative effect (negative number). HBacteria and SBacteria: the Shannon and Chao index of soil bacteria; HFungi and SFungi: the Shannon and Chao index of soil fungi; SW: soil water content; SOC: soil organic carbon; STN: soil total nitrogen; SNN: soil nitrate nitrogen; SAP: soil available phosphorus; HC: herb coverage; HB: herb biomass; LB: litter biomass; FRB: fine root biomass.

\section{Supplementary Files}

This is a list of supplementary files associated with this preprint. Click to download.

- Supplementarymaterial.docx 